\title{
Extratropical Forcing and the Burst of Equatorial Westerlies in the Western Pacific: A Synoptic Study ${ }^{1}$
}

\author{
By Pao-Shin Chu \\ Department of Meteorology, University of Hawaii, \\ Honolulu, HI 96822 \\ (Manuscript received 20 November 1987, in revised form 6 June 1988)
}

\begin{abstract}
Based on surface winds at 6-h intervals for four Northern Winters and Springs (1970-73), two cases of strong westerly wind bursts were identified in the core of the equatorial western Pacific $\left(\sim 155^{\circ} \mathrm{E}\right)$. One case occurred in early April and another in early May 1972, both prior to the maximum sea surface temperature anomalies along the Peruvian coast during the 1972 ENSO event.

During the Northern Spring, as an anomalously strong anticyclone moves rapidly from nor th-central China to its east coast, the surface wind fields to the southeast of the Philippines respond swiftly, turning from an easterly background to northerly. In the meantime, surface pressure in the far western equatorial Pacific tends to rise. These rapid equatorial resposes are probably due to gravity wave-like motions induced by the pressure-wind imbalance in the midlatitudes. The local pressure increase in the extreme western Pacific enhances the west-to-east pressure gradient in the equatorial trough zone and results in a strong westerly wind acceleration in the core of the equatorial western Pacific. This acceleration is also preceded by a west-to-east displacement of the pressure surge in the equatorial trough zone. The enhanced zonal pressure-gradient force and the associated eastward displacement of the equatorial pressure surge are two critical factors for initiating westerly wind bursts. Westerly wind surges detected primarily from fixed-station data compare favorably with those calculated from ship records of an independent source.
\end{abstract}

\section{Introduction}

During the Northern Winter, the migratory anticyclone of Siberian origin and the concomitant northeasterly cold surge occur frequently over southeast China and its adjacent seas. Following a long trajectory equatorward, northeasterly surges recurve into northwesterlies as they approach the equatorial South China Sea, and finally merge with the broad westerly current of the Australian summer monsoon. As the surge air propagates rapidly equatorward off southeast China, it is modified gradually by the relatively warm sea water in such a way that its temperature signature is no longer "cold," although a freshening of northerlies and a

(C) 1988, Meteorological Society of Japan

${ }^{1}$ Contribution No. 87-06 of the Department of Meteorology, University of Hawaii. significant pressure rise are still registered in the equatorial South China Sea (Ramage, 1971; Chang et al., 1979; Chang et al., 1983; Chu and Park, 1984). These tropical responses, along with the enhanced convection in the vicinity of Borneo, have been observed to occur within one or two days after the midlatitude forcing (Chang et al., 1979; Chang and Lau, 1980, 1982; Lau, 1982).

As the season changes to the Northern Spring, the winter monsoon of East Asia weakens and the midlatitude disturbances (i.e., anticyclones and frontal waves) slowly propagate eastward off the China coast. In the meantime, a wedge of the north-central Pacific high extends westward to southeast China (Atkinson, 1971). Circulation in low latitudes is marked by a double trough on both sides of the equator. Between these troughs 
is a narrow band of weak, equatorial westerlies, confined approximately between $130^{\circ} \mathrm{E}-150^{\circ} \mathrm{E}$ to the north of New Guinea. Occasionally, these equatorial westerlies become stronger and subsequently extend farther eastward (e.g., Rasmusson and Carpenter, 1982; Inoue and O'Brien, 1984).

One of the important features prior to most El Niño Southern Oscillation (ENSO) events is the presence of strong westerly wind anomalies (i.e., relaxation of easterly trade winds) in the equatorial western and/or central Pacific. Over the central Pacific $\left(\sim 170^{\circ} \mathrm{E}\right.$ to $\left.170^{\circ} \mathrm{W}\right)$, these anomalies (i.e., not necessary to be westerly flows) are impulsive in nature and last from one to three weeks (Luther et al., 1983). These surface westerly surges generate oceanic Kelvin waves which in turn may cause the warming of the sea surface in the eastern equatorial Pacific (e.g.., Wyrtki, 1975; McCreary, 1976; Philander, 1981; Lukas et al., 1984; Harrison and Schopf, 1984; Cane and Zebiak, 1985). This warming is apparent in all major ENSO events.

Several factors can cause a westerly wind pulse in low latitudes such as tropical cyclone development, extratropical forcing, or a combination of both. Keen (1982) recognized how tropical cyclone pairs generate equatorial westerlies over the central Pacific. Williams (1979) briefly discussed a case of an eastwardpropagating cloud disturbance in an area to the north of Australia after an East Asian midlatitude forcing. Using daily satellite cloud images, Lau (1982) documented that convection generated near Borneo had a main component which propagated eastward following the cold surge onset. As convection moved eastward, equatorial westerlies in the lower troposphere would have been expected to occur in association with convection. Based on conventional weather observations, Chu and Park (1984) as well as Love (1985) also showed that cold surges from East Asia are able to enhance surface westerlies and an eastward mass flow in the equatorial South China Sea with a time lag of two to three days. However, such a remote forcing has not been reported over the equatorial western Pacific Ocean where stations reporting regularly are rare.

Since the wind variations in the equatorial western Pacific (i.e., $130^{\circ} \mathrm{E}$ to the dateline as defined in this study) are crucial in the early phase of ENSO (Wyrtki, 1975; Barnett, 1981, 1984; Inoue and O'Brien, 1984), it is very important to identify atmospheric conditions responsible for the burst of westerlies in that region. Although tropical cyclones in this region are one of the likely generators (Ramage, 1985), extratropical forcings also seem plausible. One such forcing might have originated in the Southern midlatitudes (Harrison, 1984; van Loon and Shea, 1985). Accordingly, this paper, using the regular and special stations plus ship reports, presents evidence that midlatitude disturbances and associated monsoonal flows over East Asia also can have an effect on the equatorial winds as far southeast as New Guinea.

\section{Data sources and selection of study periods}

There are two major data sources for the large-scale analyses - Japan Meteorological Agency (JMA) and Hong Kong Royal Observatory (HKRO). JMA compiles daily synoptic reports (twice per day) and weather charts. In addition to the continental and island station observations, the JMA analysis contains ship reports. Overall, JMA has an adequate spatial coverage to about $10^{\circ} \mathrm{N}$ (Fig. 1). To fill the data-void regions in low latitudes as well as the Southern Hemisphere proper, daily weather

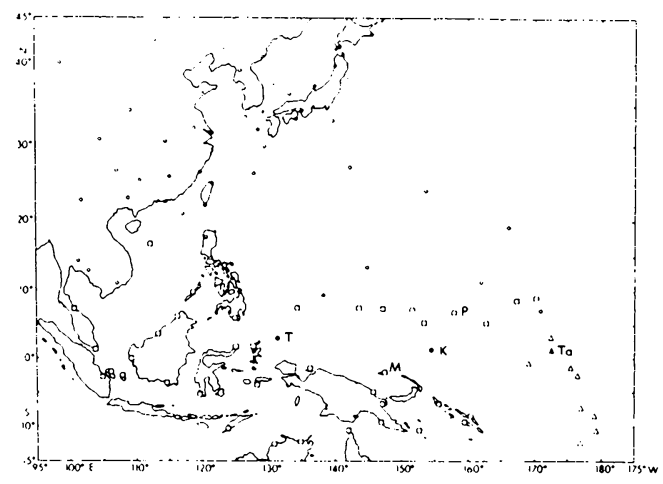

Fig. 1. Map showing the location of stations used in this investigation. Stations from JMA are indicated by open circles, from HKRO are denoted by open squares, from NZMS are shown by open triangles. Tobi $(\mathrm{T})$ and Kapingamarangi $(\mathrm{K})$ are shown by solid dots. Ta, $\mathbf{M}$, and $\mathbf{P}$ denote Tarawa, Momote, and Ponape, respectively. 
charts prepared by HKRO are employed. HKRO has a few ship reports in the equatorial areas. These ship reports provide vital information over the equatorial western Pacific (hereafter referred to as EWP) where stations are very sparse.

To monitor the low latitude circulation variations due to extratropical forcing, two key stations (Tobi and Kapingamarangi) with rather detailed and complete synoptic records are selected (Fig. 1). Data from these two stations are not routinely published by JMA or HKRO, being collected by the Department of Meteorology, University of Hawaii from National Climatic Center in Asheville, North Carolina. Since Tobi $\left(3^{\circ} \mathrm{N}, 131^{\circ} 11^{\prime} \mathrm{E}\right)$ is located to the southeast of the Philippines, wind and pressure fluctuations at this atoll will indicate an early signal, if any, of the extratropical forcing from East Asia during the Northern Winter and/or Spring. Further downstream from Tobi is Kapingamarangi atoll $\left(1^{\circ} 05^{\prime} \mathrm{N}, 154^{\circ} 46^{\prime} \mathrm{E}\right)$, a site representative of the core of the EWP. Although the wind observations at Kapingamarangi appear reasonable as compared to other reports from neighboring stations and ships, its pressure records are not. They tend to be systematically a few millibars lower. For this reason, pressure data at Kapingamarangi will not be analyzed.

In the equatorial central Pacific lie the Kiribati and Tuvalu where 00 and 12 GMT data are available in the Daily Weather Bulletins from the New Zealand Meteorological Service (NZMS). Another key station, Tarawa ' $\left(1^{\circ} 21^{\prime} \mathrm{N}\right.$, $172^{\circ} 55^{\prime} \mathrm{E}$ ), is located in this region (Fig. 1). Wind and pressure observations at Tarawa are rather complete and consistent with other adjacent stations. To help determine the low latitude circulation in the area where stations are scanty, daily mosaics of ESSA/NOAA satellite images are used.

In this investigation, a westerly wind burst in the core of the EWP, as represented by Kapingamarangi, is defined as: (a) the wind abruptly shifting to a westerly direction; (b) this westerly flow lasting for at least two consecutive days; and during which (c) at least once the westerly component speed exceeds $7 \mathrm{~ms}^{-1}$. It should be noted that this set of criteria for the burst takes into account the direction of wind change and the duration, as well as the strength of wind during the periods of westerly episodes. This definition thus ensures that a single episode, one possibly caused by observational error or random effect, will be excluded from the analysis. It also implies that only strong episodes will be included in the analysis.

Since the East Asian midlatitude forcings are most pronounced during the Northern Winter and Spring, wind records at Kapingamarangi for the period January through May plus December from 1970 to 1973 were first scrutinized. During this period seven cases met the aforementioned criteria and they all occurred in the Northern Spring(i.e., March to May). An examination of large-scale synoptic settings indicates that six out of seven cases were preceded by midlatitude influences over East Asia. However, because two out of these seven cases had very strong westerly winds $\left(15 \mathrm{~ms}^{-1}\right.$ in one case and $20 \mathrm{~ms}^{-1}$ in another case), this study will present results related to these two bursts. It was noted that some other westerly episodes were present in the equatorial central Pacific near $170^{\circ} \mathrm{W}$ during 1970-73 (e.g., Luther et al., 1983). Because the daily surface wind data in that region were not yet available to us, the present study only focuses on the short-term impact of the extratropical forcing on wind variations in the EWP and does not concentrate on the region further east.

\section{Synoptic description of the first case}

Figure 2 shows three surface pressure analyses from 31 March to 4 April 1972. At 0000 (all times refer to $0000 \mathrm{GMT}$ ) on 31 March (Fig. 2a), an unusually strong and cold anticyclonic cell dominates north-central China. The surface pressure and temperature near the core of the anticyclone are $1047 \mathrm{mb}$ and $-15^{\circ} \mathrm{C}$, respectively. This feature is rather unusual at this time of the year. Another high-pressure system is evident over the northwest Pacific. Sandwiched between these two anticyclones is a low pressure center with a cold front which extends from Japan southwestward to the Luzon Strait. In the EWP is a pressure trough which is delineated by the $1008 \mathrm{mb}$ isobar. Within this trough exists an unnamed tropical depression (i.e., wind speeds 

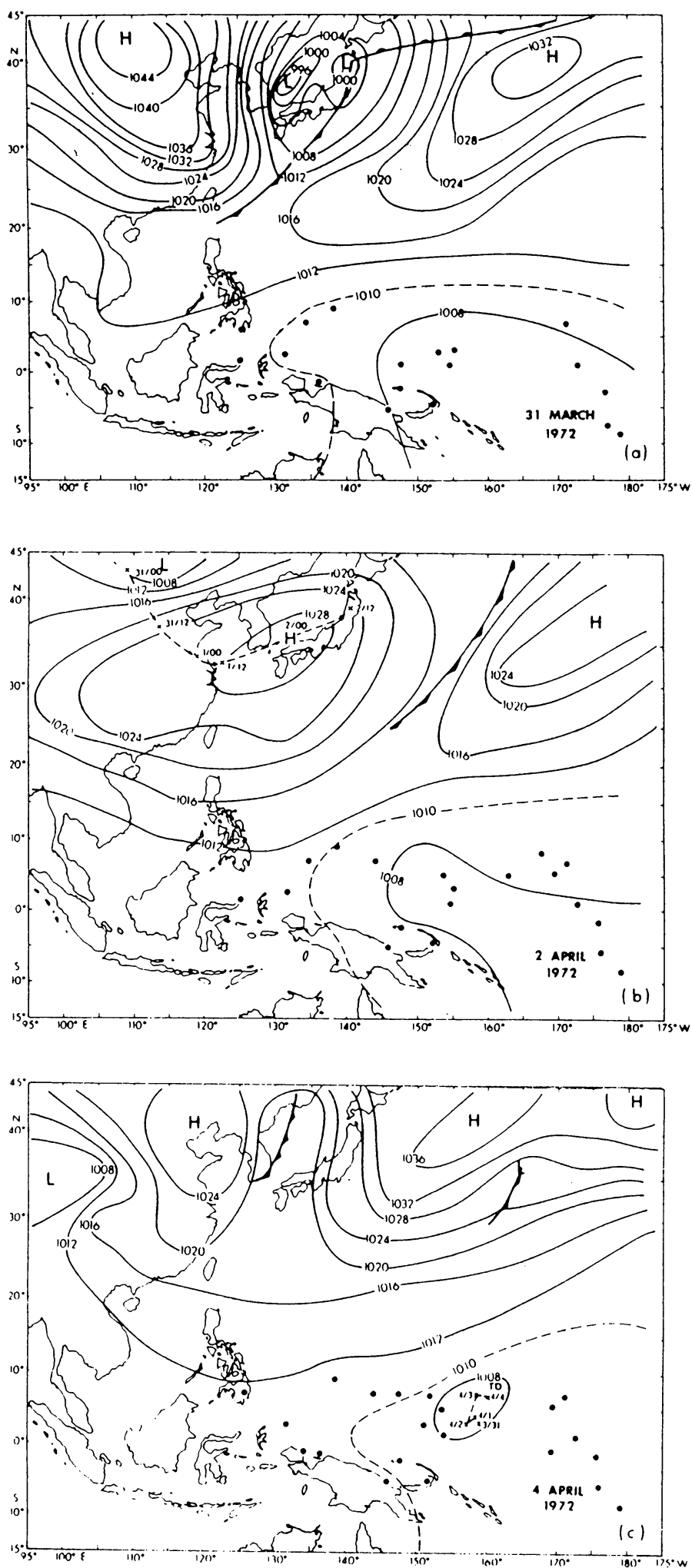
are less than $17 \mathrm{~ms}^{-1}$ ) as identified by the Joint Typhoon Warning Center (JTWC) in Guam. Its position is indicated in Fig. 2c. Because pressure variations in the equatorial regions are very small, the isobars there are drawn at 2-mb interval.

Two days later (Fig. 2b), a polar-outbreak high, previously centered in north-central China, progresses southeastward to the Korea Strait. With the encroachment of the high-pressure cell from China, the $1012 \mathrm{mb}$ isobar to the east of the Philippines advances about $500 \mathrm{~km}$ southward. By comparing the analyses for Figs. $2 \mathrm{a}$ and $2 b$, we note that sea level pressure over the western extreme of the EWP has changed from a value less than $1010 \mathrm{mb}$ on 31 March to a value more than $1010 \mathrm{mb}$ on 2 April. Meanwhile, there is also an indication of a pressure surge from the extreme Western Pacific, as evidenced by the eastward movement of the $1010 \mathrm{mb}$ isobar (Figs. $2 a$ and $2 b$ ).

Further evidence on the extratropical forcing is shown in Fig. 3, where the pressure deviation is plotted as a function of time for seven locations, at every $5^{\circ}$ latitude interval, lying along the $130^{\circ} \mathrm{E}$ meridian. It shows a pressure pulse starting at $30^{\circ} \mathrm{N}$ near 00001 April and arriving at the equator about a day later. This pressure pulse, associated with a strong polar high is the Northern Spring (Figs. 2a and 2b), traveled meridionally at a speed of about $40 \mathrm{~ms}^{-1}$. This propagation speed is much faster than the advection speed associated with the cold front (i.e., $12 \mathrm{~ms}^{-1}$; Chu and Sikdar, 1983). It is thus recognized that the propagation of this pressure pulse, as induced by a strong baroclinic wave activity in midlatitudes, is in the form of a gravity wave.

A similar phenomenon was also found in the

Fig. 2. Surface isobaric analysis for (a) $31 \mathrm{March}$ (b) 2 April, and (c) 4 April 1972. All times refer to 0000 GMT. Trajectory of the East Asian anticyclone is denoted by a broken line in (b). Day and hour are indicated accordingly. Only the anticyclone with a closed center is shown. Dots denote stations in the equatorial western Pacific (10N-10S) used in the individual analysis. The center of the unnamed tropical depression from 31 March to 4 April 1972 is denoted by $\mathrm{X}$ in (c). Month and day are indicated accordingly.
South China Sea during the Winter MONEX. Chang et al. (1983) identified that cold surges were marked by two different stages. While the second stage is associated with a frontal passage, the first stage, which is marked by a significant pressure rise, is associated with synoptic scale gravity wave-type motion. This pressure rise in Fig. $2 \mathrm{~b}$ will also be seen in a more detailed temporal analysis for a single station (i.e., Tobi in Fig. 7b).

Throughout the course of the next 48 hours, the high pressure continues its eastward displacement to the east of Japan and the accompanying low pressure center loses its intensity to become a frontal wave (Fig. 2c). The $1010 \mathrm{mb}$ isobar to the north of New Guinea moves further eastward from about $135 \mathrm{E}$ on 2 April to about $140 \mathrm{E}$ on 4 April. The unnamed tropical depression remains in approximately the same position throughout

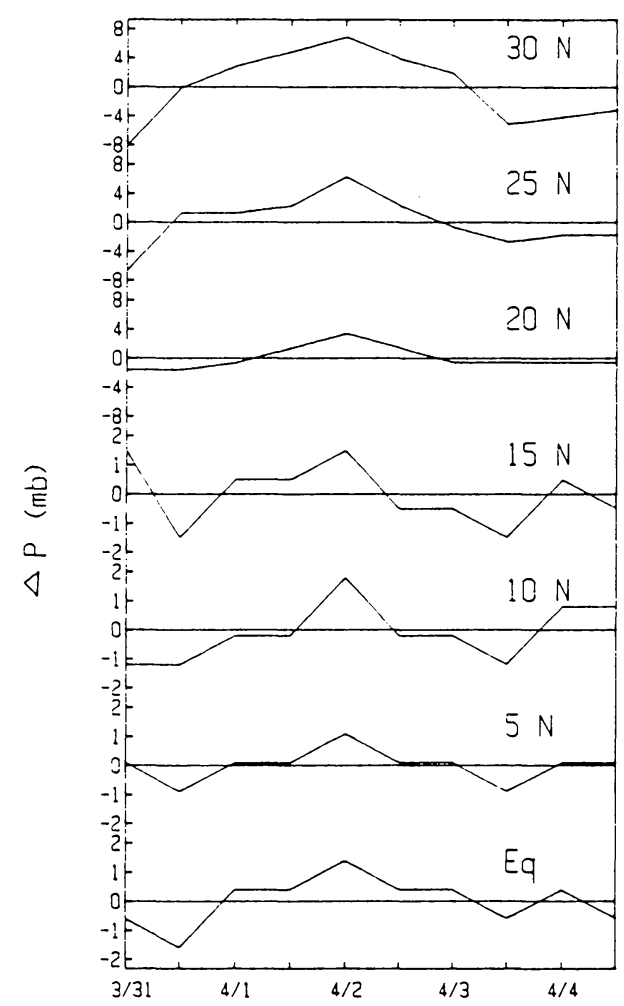

Fig. 3. Surface pressure deviation $(\mathrm{mb})$ for seven locations along the $130^{\circ} \mathrm{N}$ meridian (extreme western Pacific) as a function of time for the period 31 March to 4 April 1972. All deviations refer to departures from local time averages. 
the entire period. It was last reported on 4 April by JTWC.

To study the response of the equatorial winds to extratropical forcing, surface streamline analysis from 31 March to 5 April is presented. On 31 March (Fig. 4a), the EWP is marked by the double trough, one in each hemisphere with light westerlies in between. The easterlies predominate to the east of the Philippines. By 1 April, as the polar outbreak pushes farther southeastward (Fig. 2b), the prevailing wind direction in the
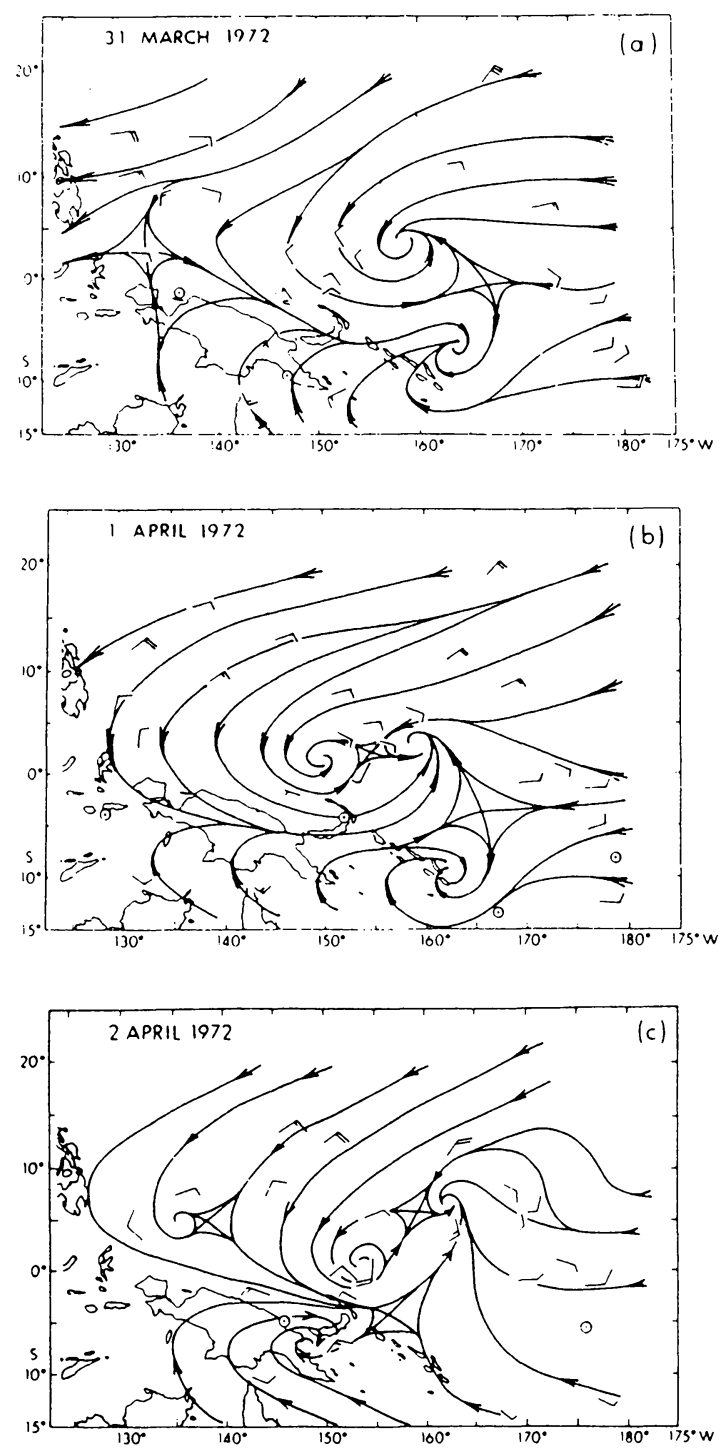

western Pacific adjacent to the Philippines becomes more northerly (Fig. 4b). It is interesting to note that when a cold surge reaches Hong Kong a freshening of the northerly winds can occur almost simultaneously in an area more than several hundred miles south in the equatorial South China Sea (e.g., Ramage, 1971; Chang et al., 1979). Such effects are also noticeable in our current analysis at 120031 March. At that time, the winds had become more northerly as reported by two ships located near
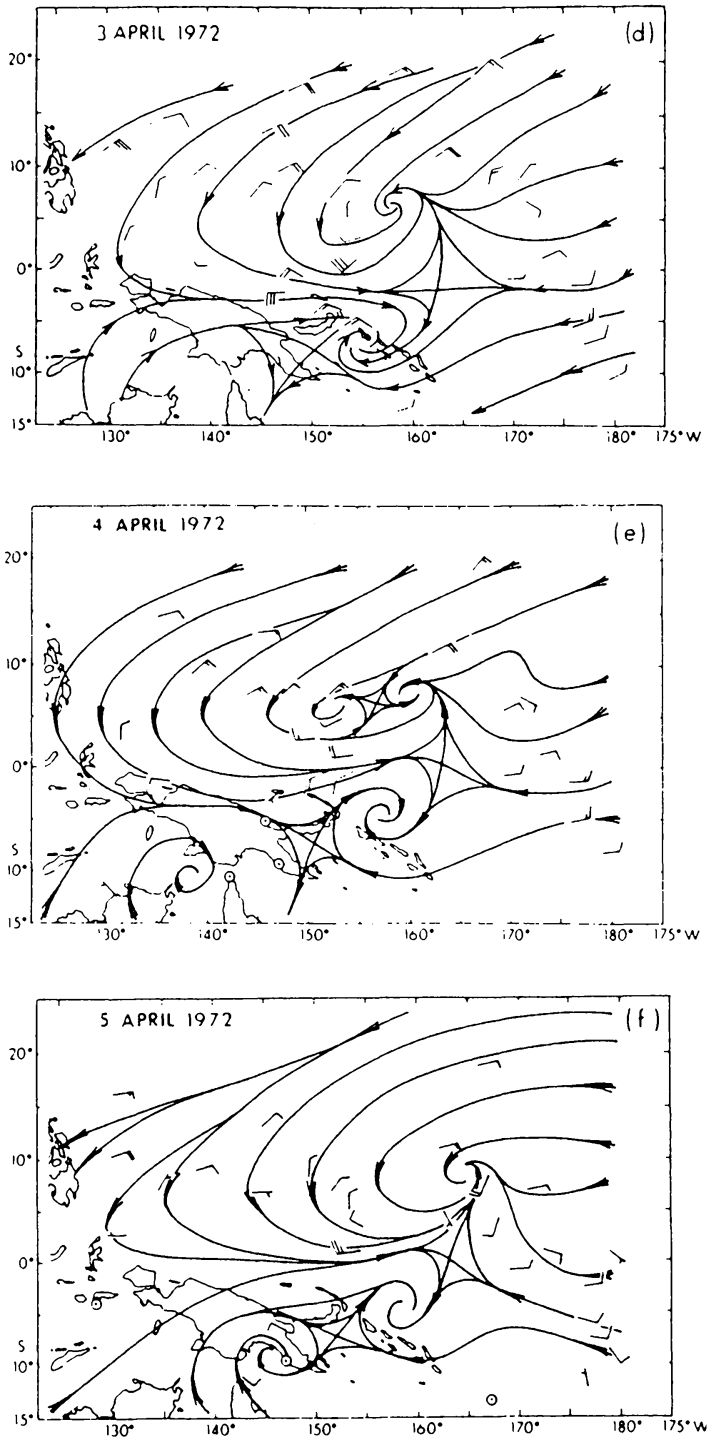

Fig. 4. Surface streamline analysis for (a) 31 March, (b) 1 April, (c) 2 April, (d) 3 April, (e) 4 April, and (f) 5 April 1972. Long barbs: $5 \mathrm{~ms}^{-1}$; short barbs: $2.5 \mathrm{~ms}^{-1}$. All times are $0000 \mathrm{GMT}$. 
$5^{\circ} \mathrm{N}, 110^{\circ} \mathrm{E}$ (not shown). The almost immediate turning of the wind fields ( $\sim 1$ day) from easterlies to northerlies, together with the pressure rise (Figs. $2 \mathrm{~b}$ and 3 ), in the area to the southeast of the Philippines are most interesting. These equatorial responses are much faster than the advection speed from the leading edge of the cold anticyclone as seen in Fig. 2.

Upon reaching the elevated island chains, the northerly flows encounter a barrier to its south (New Guinea) and west (Molucca), resulting in an observed anticlockwise wind turning at Tobi (Fig. 4c). This cyclonic turning of the wind is also expected from the conservation of absolute vorticity as air moves equatorward. A band of equatorial westerlies is first noted between 144E and 153E. Twenty-four hours later on 3 April (Fig. 4d), the westerly flow appears to accelerate more and covers from about $140 \mathrm{E}$ to $156 \mathrm{E}$ near the equator. This band of westerly current was observed by four ships, two atoll stations and an island (Momote in the Admiralty Islands). On 4 April (Fig. 4e), a band of strong equatorial westerlies is still found between $150 \mathrm{E}$ and $155 \mathrm{E}$ and these strong westerlies continue throughout the next 24 hours (Fig. 4f).

The 10 to $15 \mathrm{~ms}^{-1}$ westerly wind burst observed to the north of New Guinea (e.g., Fig. 4d) is particularly unusual since the long-term averaged westerly wind speed in this area is less than $2 \mathrm{~ms}^{-1}$ (Fig. 5a). One explanation for this sudden increase in westerlies is the tropical
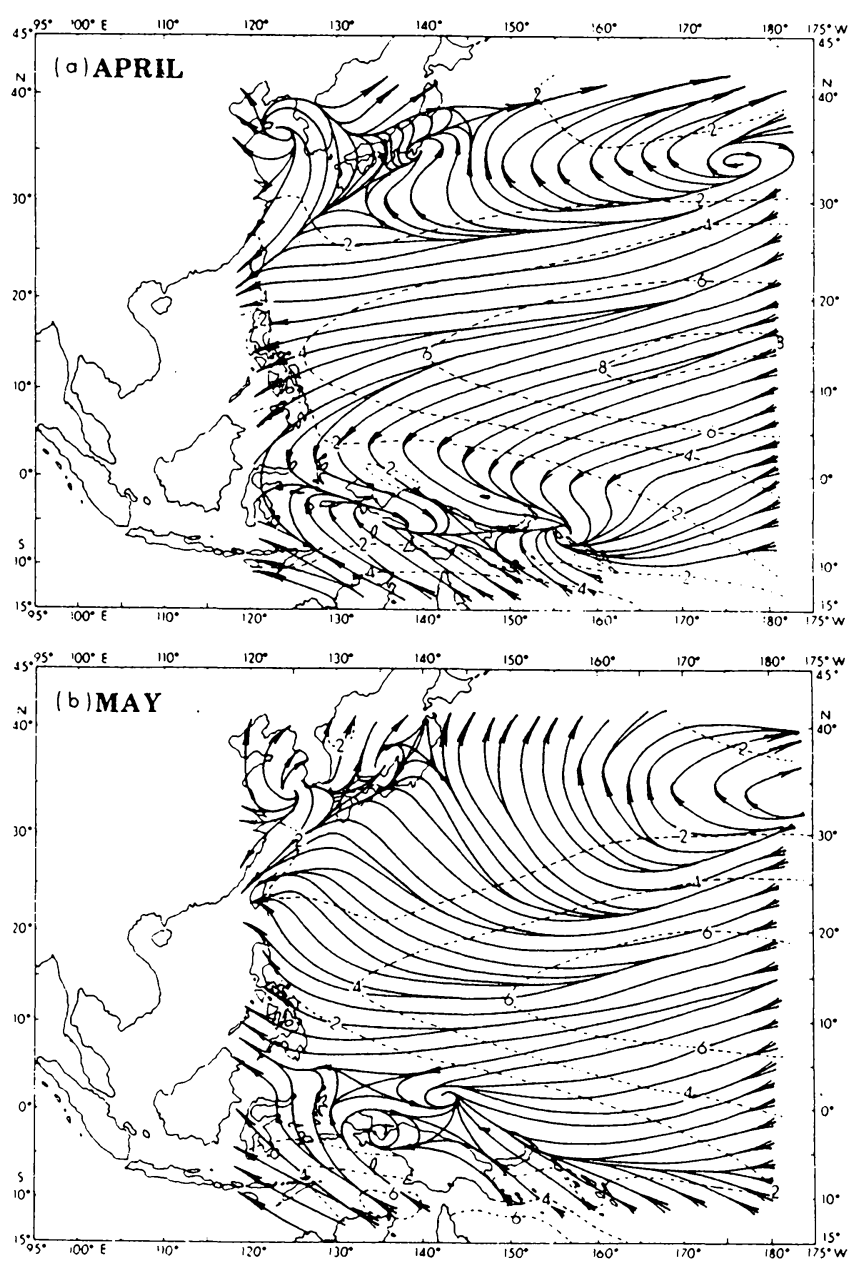

Fig. 5. Long-term monthly mean surface streamline/ isotach $\left(\mathrm{ms}^{-1}\right)$ analysis from COADS for (a) April and (b) May. (After Sadler et al., 1987). 
depression which lingered near Ponape since 30 March (see Figs. 1 and 2). However, according to satellite images and JTWC, this depression exhibits neither a pronounced shift in zonal movement nor a change in intensity from 30 March to 3 April (Fig. 2c). Further analysis of tropical convective systems using daily satellite mosaics also indicates a lack of cyclonic inflows spiraling toward the center of this depression. It thus seems unlikely that the strong westerlies observed to the northeast of New Guinea were induced by the tropical depression. In fact, the formation of the twin vortices, nearly symmetrically with respect to the equator, might be caused by the strong equatorial westerlies since they act to enhance cyclonic shear on the equatorward sides of the vortices (Fig. 4d). From 3 to 4 April (Fig. 2c), this depression moves eastward by about $200 \mathrm{~km}$, as a result of the enhancement of the westerlies over the western portion of the EWP.

Figure $6 a$ shows the temporal variations of surface winds at 6-h intervals at Tobi during the period from 29 March to 8 April 1972. The easterly winds prior to 120031 March give way to the northerly winds during the first three days of April. Note the persistent northwesterlies from 06001 April to 18002 April. At Kapingamarangi (Fig. 6b), a strong westerly wind burst occurs at 18002 April and reaches

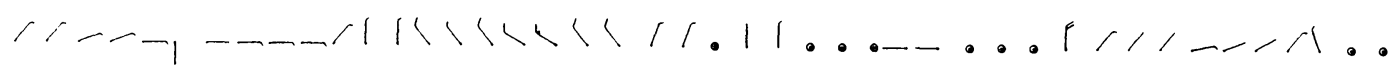

(B) KAPINGAMARANG I

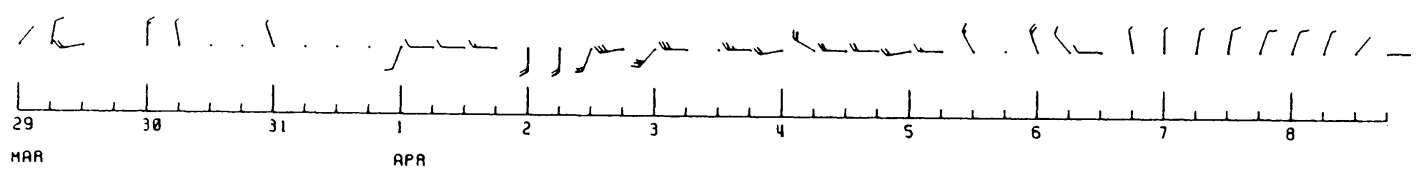

Fig. 6. Time series of surface wind observations at 6-h interval for (a) Tobi and (b) Kapingamarangi for the period 29 March to 8 April 1972. Long barbs: $5 \mathrm{~ms}^{-1}$; short barbs: $2.5 \mathrm{~ms}^{-1}$. Dot with enclosed circle denotes calm.
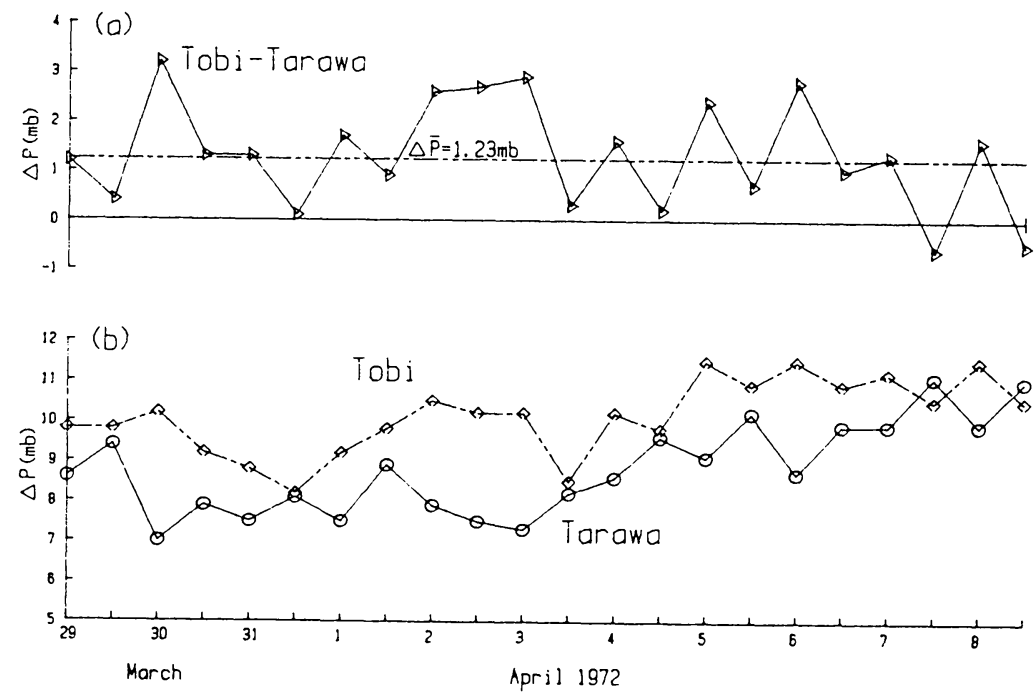

Fig. 7. (a) Time series of sea level pressure (Tobi minus Tarawa) from 29 March to 8 April 1972. (b)

Time series of individual pressure series for Tobi (broken) and Tarawa (solid). 
maximum (i.e., $15 \mathrm{~ms}^{-1}$ ) at 06003 April. The westerly wind burst at Kapingamarangi remains until 5 April and lasts for about four days.

Figure $7 \mathrm{a}$ shows the temporal variations of Tobi-minus-Tarawa sea level pressure. Values are above the mean difference $(1.23 \mathrm{mb})$ from 0000 2 April to 00003 April and these large west-to-east down pressure gradients occur before the westerly bursts observed in the core of the EWP (Fig. $6 \mathrm{~b}$ or 4 ). An examination of Tobi pressure series (Fig. $7 \mathrm{~b}$ ) reveals values increasing successively from 120031 March to 00002 April, possibly reflecting the effect of the gravity wavelike transient motion induced by the pressure-wind imbalance in midlatitudes. This pressure rise at Tobi, together with a decrease of pressure at Tarawa, contributes to a large pressure gradient as noted above.

The local zonal wind acceleration for frictionless flows over the open ocean surface can be calculated using the zonal momentum equation:

$$
\frac{\partial u}{\partial t}+u \frac{\partial u}{\partial x}+v \frac{\partial u}{\partial y}+w \frac{\partial u}{\partial z}-f v=-\frac{1}{\rho} \frac{\partial p}{\partial x}
$$

In practice, the vertical velocity at the surface is smaller than the other terms and is difficult to estimate accurately. Neglecting this term, (1) then becomes:

$$
\frac{\partial u}{\partial t}=-u \frac{\partial u}{\partial x}-v \frac{\partial u}{\partial y}+f v-\frac{1}{\rho} \frac{\partial p}{\partial x}
$$

We can now evaluate how each term on the right hand side of (2) contributes to the local wind acceleration. Consider, as an example, the case of 3 April when a band of westerlies appeared to be strengthened north of New Guinea (Fig. 4d). Given the actual observations of sea level pressure at Tobi and Tarawa (Fig. 7), the estimated magnitude of the zonal pressure gradient $\left(-\frac{1}{\rho} \frac{\partial p}{\partial x}\right)$ is about $6.280 \times 10^{-5} \mathrm{~ms}^{-2}$.

Since pressures in the equatorial central Pacific are generally lower than those in the far western (e.g., Fig. 2), the zonal pressure gradient, based on the Tarawa-minus-Tobi series, is thus positive.
There are approximate estimates of $u \frac{\partial u}{\partial x} \cong$ $0.251 \times 10^{-5} \mathrm{~ms}^{-2}$, of $v \frac{\partial u}{\partial y} \cong 0.672 \times 10^{-5} \mathrm{~ms}^{-2}$ and of $f v \cong-1.145 \times 10^{-5} \mathrm{~ms}^{-2}$.

The above computations are made based upon values at four gridpoints (i.e., Tobi, Tarawa, $10^{\circ} \mathrm{N}, 152^{\circ} \mathrm{E}$, and $10^{\circ} \mathrm{S}, 152^{\circ} \mathrm{E}$ ) so that the center of the network is at $2^{\circ} \mathrm{N}, 152^{\circ} \mathrm{E}$. This particular longitude is chosen since it lies midpoint between Tobi and Tarawa. To evaluate the term $f v, v$ is obtained as an average of the meridional wind component from four grids and $f$ is calculated at $2^{\circ} \mathrm{N}$. Because the advective acceleration terms are about one order of magnitude smaller than the pressure gradient and the Coriolis acceleration, the main balance is:

$$
\frac{\partial u}{\partial t} \cong-\frac{1}{\rho} \frac{\partial p}{\partial x}+f v
$$

With the estimated zonal pressure gradient and the Coriolis terms, the local zonal wind acceleration between Tobi and Tarawa from (3) is approximately $4.44 \mathrm{~ms}^{-1}$ per day, which is consistent with the westerly acceleration observed near $0^{\circ}, 150^{\circ} \mathrm{E}$ where an increase of about $5 \mathrm{~ms}^{-1}$ per day from 2 to 3 April was noted. The approximate balance (3) expresses the importance that the zonal pressure gradient is a leading term in the remaining balance equation, for this term is generally five times larger than the Coriolis force throughout the period of analysis. Computations for the force balance during the entire period also indicate the insignificance of the advective acceleration terms as compared to other terms in (2). However, the omission of friction, which is not directly known from the data, may result in an overestimation of the calculated zonal wind acceleration because frictional force acts in opposition to the direction of the wind and thus would reduce wind speed.

The pressure rise in the extreme Western Pacific and an eastward movement of a pressure surge in the EWP following a Spring surge have important implications for the local wind variations. Since the pressure gradient is normally very slack in the EWP in the Northern Spring 

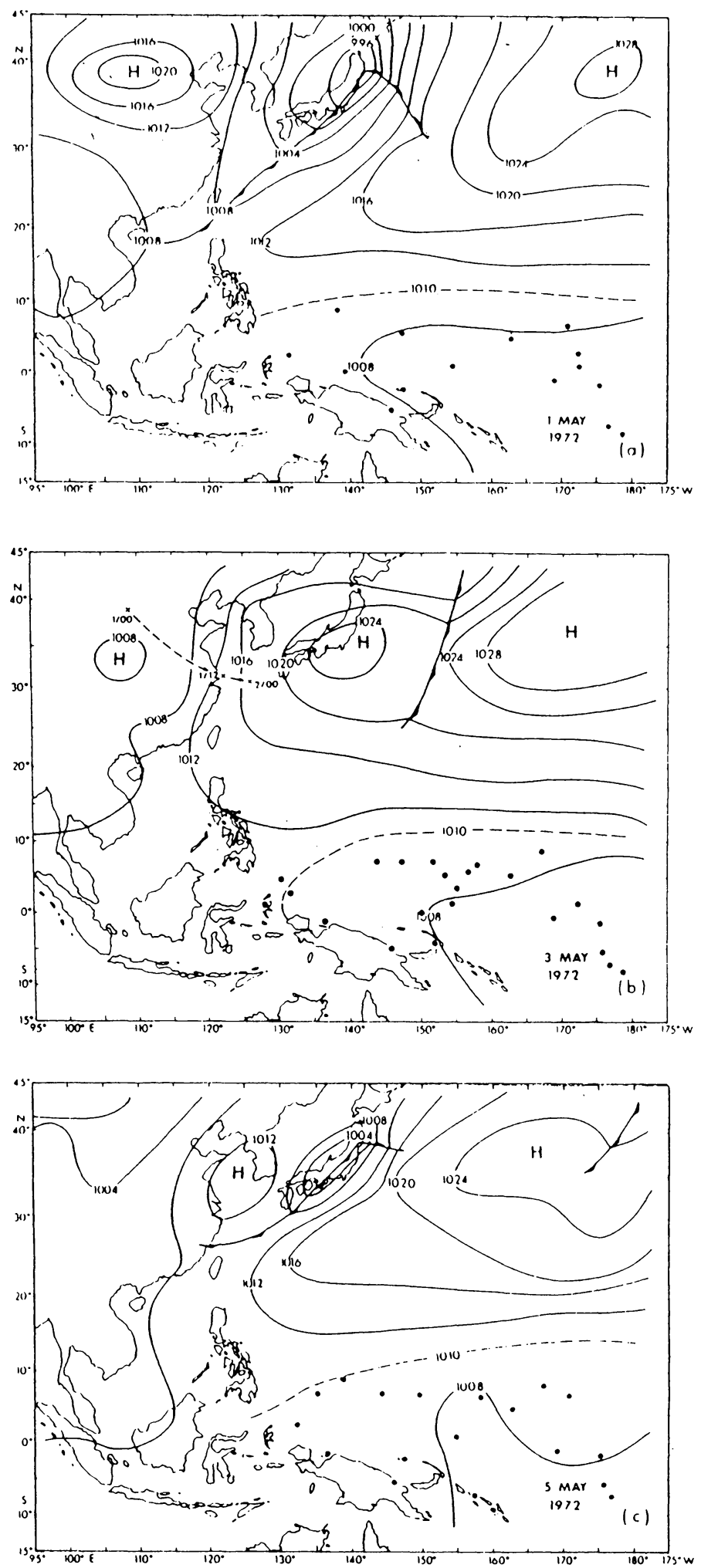
(Sadler et al., 1987), a slight pressure increase in the extreme Western Pacific would enhance the west-to-east pressure gradient within the nearequatorial trough zone. The enhanced zonal pressure gradient is then conducive to a westerly wind acceleration as expected from the equatorial dynamics.

\section{Synoptic description of the second case}

Figure 8 illustrates the temporal variations of surface pressure fields from 1 May to 5 May 1972. On 1 May (Fig. 8a), the noteworthy features are the presence of an anticyclone in central China, a baroclinic wave over Japan, and a high pressure cell over the north-central Pacific. This pattern is similar to that observed in the first case (see Fig. 2a). In contrast to the first case, the pressure and temperature near the core are only $1021 \mathrm{mb}$ and $4^{\circ} \mathrm{C}$, respectively. The $1010 \mathrm{mb}$ isobar in the western Pacific moves southeastward from Mindanao on 1 May to nearby Tobi on 3 May (Figs. 8a and b). The low latitude response to this midlatitude forcing is also seen in Fig. 9, in which a pressure pulse starts at $30^{\circ} \mathrm{N}$ near 00002 May and arrives at the equator in the extreme Western Pacific just a day later. Two days later on 5 May (Fig. 8c), although the $1010 \mathrm{mb}$ isobar does not continue to move eastward, the $1009 \mathrm{mb}$ isobar does (not shown). This is also in agreement with the slowly diminishing area of the pressure trough over the EWP throughout this entire period (Figs. 8a, 8b, $8 c)$. No tropical cyclones (i.e., typhoons, storms, or depressions) occur during this period.

Figure 10 gives the surface streamline analysis from 1 May to 6 May 1972. Similar to the first case (Fig. 4), the surface circulation over the EWP features a double trough, one in each hemisphere. At this time, the near-equatorial trough to the north of New Guinea is more energetic than the long-term average (see Fig. $5 b)$. The other trough in the vicinity of southern New Guinea, however, is not shown in the

Fig. 8. Surface isobaric analysis for (a) $1 \mathrm{May,} \mathrm{(b)} 3$ May, and (c) 5 May 1972. All times are 0000 GMT. Trajectory of the East Asian anticyclone is denoted by a broken line in (b). Only the anticyclone with a closed center is shown. long-term climatology.

On 1 May (Fig. 10a), a cyclonic vortex appears to the east of Mindanao and the surrounding flows are southeasterly and westerly at Koror $\left(7^{\circ} 20^{\prime} \mathrm{N}, 134^{\circ} 29^{\prime} \mathrm{E}\right)$ and Tobi, respectively.Twenty-four hours later on 2 May, as the midlatitude anticyclone moves rapidly southeastward to the East China Sea (see Fig. 8b), winds at Koror and Tobi turn to more northerly (Fig. 10b). By 3 May (Fig. 10c), northeast flows at Tobi and its adjacent area, together with northerlies at Molucca, are still discernible. A slight backing of winds from northeasterly to northerly at Tobi is noted on 4 May (Fig. 10d). On 5 May (Fig. 10e), a burst of westerlies ( 10 $\left.\mathrm{ms}^{-1}\right)$ is registered in the core of the EWP and these westerlies continue to be present until 6 May (Fig. 10f). Note that the long-term averaged surface wind in the vicinity of Kapingamarangi is easterly and the speed is less than $2 \mathrm{~ms}^{-1}$ (see Fig. 5b). Throughout the entire period, a

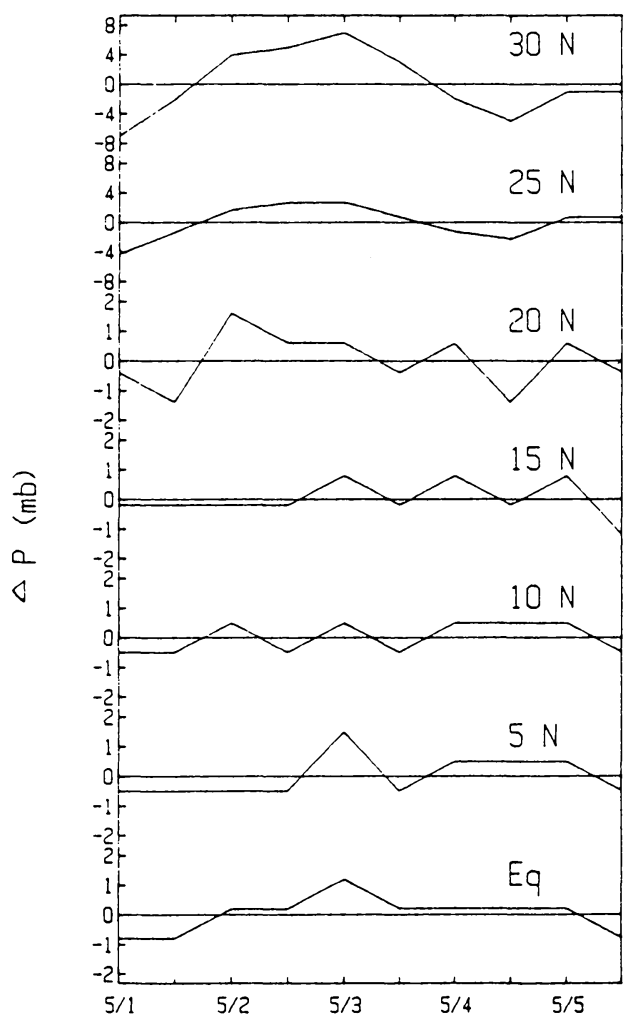

Fig. 9. Same as Fig. 3, but for the period 1 to 5 May 1972. 
cyclonic vortex is present to the north or east of Kapingamarangi, but this vortex does not develop into a tropical cyclone.

Figure 11a displays the surface wind variations at Tobi from 28 April to 8 May 1972. A fairly long period of northerly winds occurs between 18001 May and 18004 May. At Kapingamarangi (Fig. 11b), a strong westsouthwesterly flow becomes evident at 12004 May. This marks the beginning of a $48-\mathrm{h}$ period when the winds are rather uniform in a westerly direction. Note the conspicuous increase in westerly winds from 12004 May to 06005 May,
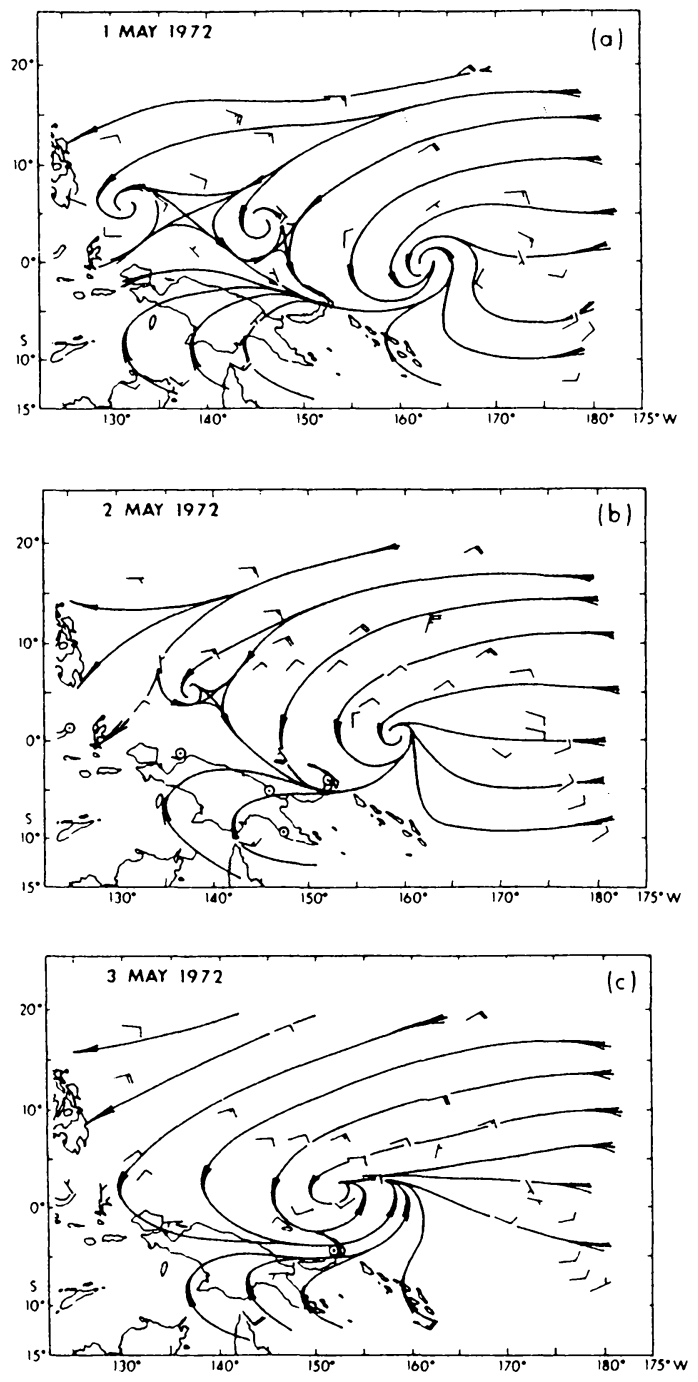

which lags an escalation of zonal down pressure gradient between Tobi and Tarawa (Fig. 12a). From 12001 to $00004 \mathrm{May}$, an increase in pressure at Tobi and a rather constant pressure level at Tarawa are noticed (Fig. 12b), prior to the westerly burst at Kapingamarangi (Fig. 11b).

\section{Summary and discussion}

Based upon data from four Northern Winters and Springs, two cases of strong westerly wind bursts in the core of the EWP are identified. These two cases occur in the Northern Spring of 1972. The forcing mechanism of these two cases
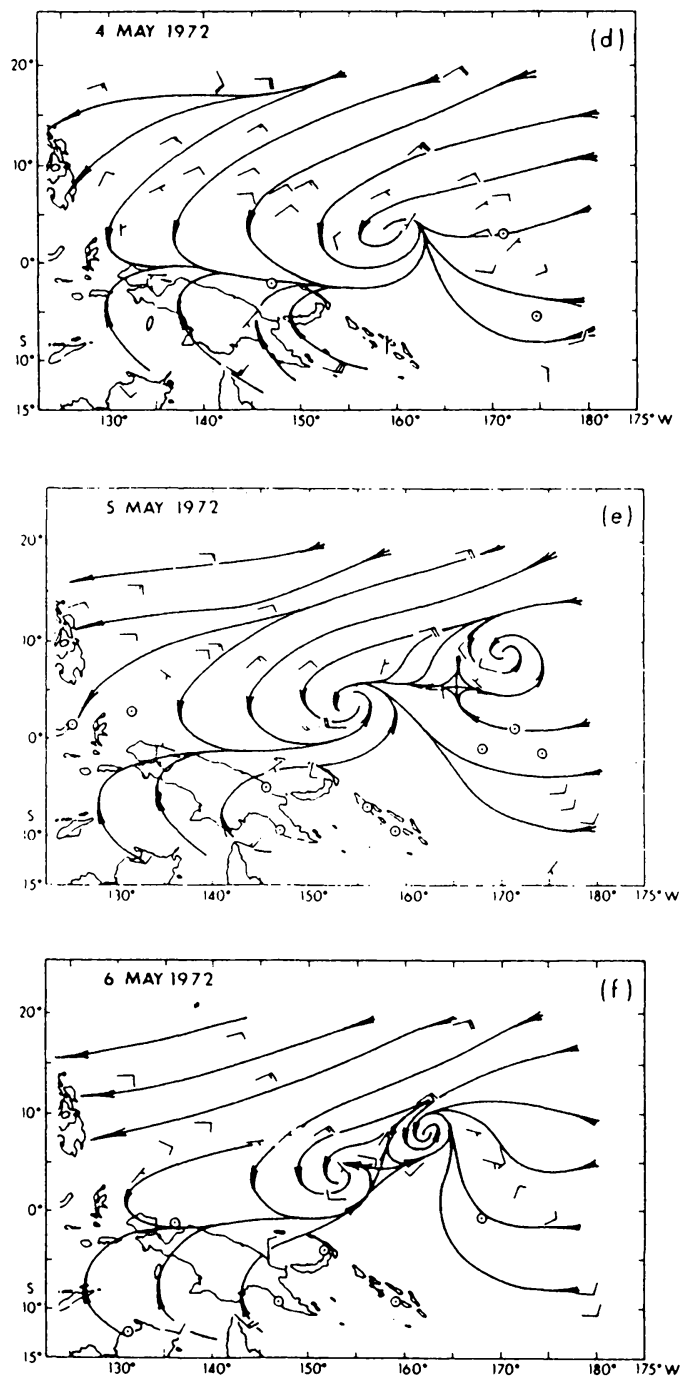

Fig. 10. Surface streamline analysis for (a) 1. May, (b) 2 May, (c) 3 May, (d) 4 May, (e) 5 May, and (f) 6 May 1972. Long barbs: $5 \mathrm{~ms}^{-1}$; short barbs: $2.5 \mathrm{~ms}^{-1}$. All times are $0000 \mathrm{GMT}$. 
(A) TOB I

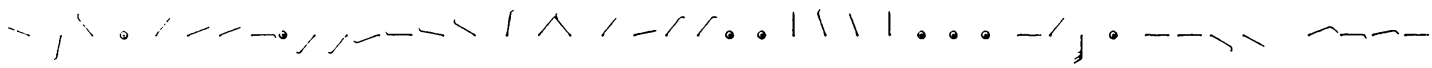

(B) KAPINGAMARANGI

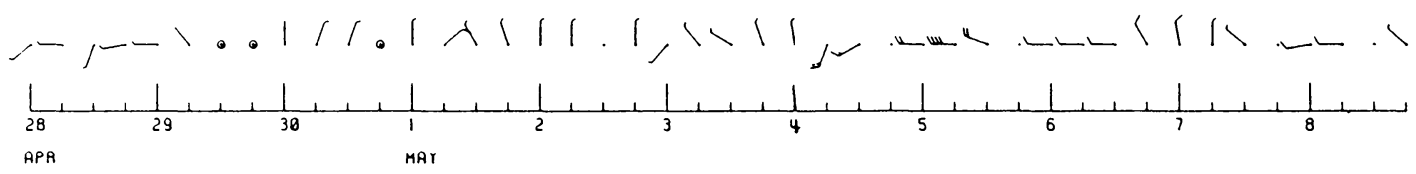

Fig. 11. Same as Fig. 6, but for the period 28 April to 8 May 1972.
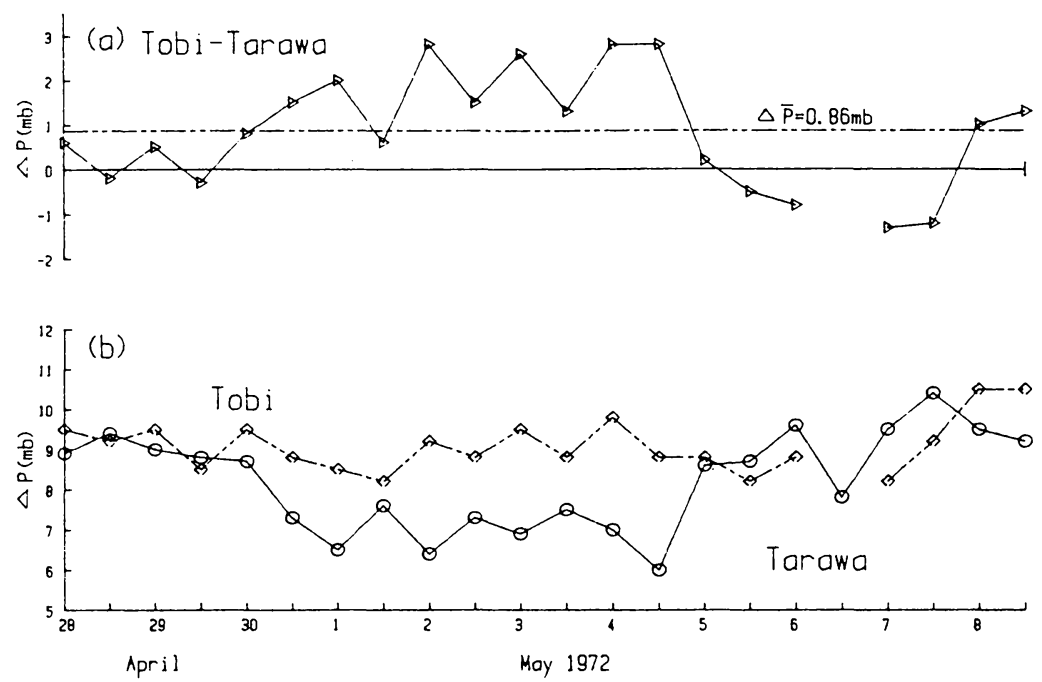

Fig. 12. Same as Fig. 7, but for the period 28 April to 8 May 1972.

is not "random," but is subject to large synoptic-scale fluctuations from East Asia. Results of these two cases are similar in many respects.

As an anomalously strong anticyclone progresses rapidly southeastward from central China to the East China Sea, the surface wind fields in the extreme western equatorial Pacific respond swiftly, turning from an easterly or northeasterly background to northerly. In the meantime, surface pressures in this same area rise. These two features occur in an equatorial region far away from the main pressure perturbation area to the north. It is thus suspected that the freshening of the northerlies and the abrupt pressure rise in the far western equatorial Pacific appear to be due to gravity waves.

The pressure rise in the extreme Western Pacific is very important for the downstream wind variations, particularly in the Northern Spring. This is the time when a climatologically double trough exists on both sides of the EWP, setting the background for weak, equatorial westerlies. However, significant westerly wind acceleration would not occur unless the basic zonal pressure fields were perturbed. As the pressure rise associated with a strong Spring surge reaches the extreme Western Pacific, the pressure gradient within the near-equatorial trough is enhanced. Under this condition, air near the equator will accelerate almost directly from regions of high pressure to regions of low 
Table 1. Time series of box-averaged zonal wind component $\left(\mathrm{ms}^{-1}\right)$ from ship observations. The box is bounded by $3 \mathrm{~N}-3 \mathrm{~S}, 140 \mathrm{E}-160 \mathrm{E}$. Standard deviation $(\sigma)$ of the box-averaged zonal wind component is also shown.

(a)

\begin{tabular}{lrc}
$\begin{array}{c}29 \text { March-8 } \\
\text { April } 1972\end{array}$ & $\mathrm{u}$ & $\begin{array}{c}\text { Number of } \\
\text { observations }\end{array}$ \\
\hline 29 March & 0.9 & 4 \\
30 & 2.5 & 1 \\
31 & 2.3 & 9 \\
1 April & 4.0 & 3 \\
2 & 7.3 & 6 \\
3 & 7.3 & 11 \\
4 & 7.4 & 9 \\
5 & 6.1 & 7 \\
6 & 3.7 & 5 \\
7 & -3.0 & 5 \\
8 & 0.2 & 8 \\
$\sigma$ & 3.37 &
\end{tabular}

(b)

\begin{tabular}{|c|c|c|c|}
\hline & $\begin{array}{l}\text { A pril-8 } \\
\text { y } 1972\end{array}$ & $\mathrm{u}$ & $\begin{array}{l}\text { Number of } \\
\text { observations }\end{array}$ \\
\hline 28 & April & 1.0 & 7 \\
\hline 29 & & 1.3 & 10 \\
\hline 30 & & 1.3 & 4 \\
\hline 1 & May & 2.9 & 10 \\
\hline 2 & & 2.8 & 8 \\
\hline 3 & & -0.4 & 8 \\
\hline 4 & & 8.3 & 4 \\
\hline 5 & & 4.1 & 6 \\
\hline 6 & & 2.6 & 3 \\
\hline 7 & & 1.5 & 13 \\
\hline 8 & & 3.3 & 7 \\
\hline$\sigma$ & & 2.27 & \\
\hline
\end{tabular}

pressure because of a weak Coriolis force and a relatively strong eastward-directed pressure gradient force. This enhanced pressure gradient force and the associated eastward displacement of the equatorial pressure surge are critical factors for initiating westerly wind acceleration in the core of the EWP.

To check the validity of the westerly wind surges based primarily on both a few fixed stations and ship reports from HKRO (e.g., Fig. 4d), ship wind records from an independent data source are used. Lander et al.* (1987) recently compiled these daily ship winds for a region bounded by $3^{\circ} \mathrm{N}-3^{\circ} \mathrm{S}$ and $140^{\circ} \mathrm{E}-160^{\circ} \mathrm{E}$ from Comprehensive Ocean-Atmosphere Data Sets (COADS). Note that Kapingamarangi and Momote are situated well within this region. Table 1 lists the time series of the daily zonal mean wind speed, the number of ship observations used and the standard deviation of the zonal wind speed. In Table 1a, an increase in the westerly flows is noted between 31 March and 1 April and it continues until 5 April, a feature consistent with Fig. $6 \mathrm{~b}$. During the period of $2-4$ April, the westerly wind speed exceeds two standard deviations. For the second case, a

* Lander, M., M. Morrissey, and J. Maliekal, 1987: Private communication. similar increase in the westerly flows is found between 30 April and 1 May and reaches a peak value on 4 May when the value is more than three standard deviations (Table $1 \mathrm{~b}$ ). As a result of the spatial and temporal averaging, wind speeds determined from ship records tend to be less than those obtained from a single station. Overall, there is agreement between the ship data and the atoll/island records.

One of the many interesting aspects of this study concerns the timing of the two episodes (i.e., April and May 1972) associated with the 1972-73 ENSO event. It is noted that the sea surface temperature anomalies at Puerto Chicama and Chimbote along the Peruvian coast reached a peak in Summer 1972 (Ramage, 1975; Wyrtki, 1975). It is also well known that the first baroclinic mode of the oceanic Kelvin wave takes about two months to cross the Pacific basin, with higher modes taking a longer time (e.g., Gill, 1982). Should the Kelvin wave be excited by the anomalously strong westerlies observed near north of New Guinea in early April and May, it would force a downwelling response at the eastern boundary. With the depressed thermocline and an eastward advection of warm water associated with the waves, an anomalous warming of sea water along the west coast of South America would be expected in June or 
July. This timing coincides with the large, positive sea surface temperature anomalies in the eastern Pacific as observed in the Summer of 1972.

Because only two episodes were surveyed, one should not get the impression that extratropical forcing always leads to the occurrence of the equatorial westerlies in the western Pacific. On occasion, pronounced forcing did not produce westerlies (e.g., early March 1971). After examining a few cases when the forcing was strong, it was tentatively found that non-westerly cases in the equatorial western Pacific are generally associated with slow moving or quasi-stationary anticyclones over northeast China. On the other hand, fast moving anticyclones such as those shown in Figs. 2 and 8 of ten cause the occurrence of westerlies. Indeed, more case studies are necessary to distinguish further the different conditions in the midlatitudes that characterize the equatorial westerlies or non-westerlies in the western Pacific. One such study is currently being planned.

\section{Acknowledgements}

I would like to thank Professor C. S. Ramage for his suggestion on the use of wind data at Tobi and Kapingamarangi for this investigation and also Professor J. C. Sadler for his discussion of the streamline analysis. The critiques of Professors Ramage, Lukas, Sadler, Schroeder, and the reviewers greatly improved the manuscript. Discussions with Professor T. Murakami have led to a better focus in the manuscript. I also benefited from discussions with Professor Y.-L. Chen. Thanks are also due to L. Oda and W. Sumathipala for drafting most of the figures, to M. Higa for assisting with data collection, and to S. Arita for typing the manuscript. M. Lander and M. Morrissey provided their ship data and computer program for retrieving daily wind records from COADS.

This research is supported by NOAA under contracts NA80RAH00002 and NA85ABH00032 to JIMAR at the University of Hawaii.

\section{References}

Atkinson, G. D., 1971: Forecasters' guide to tropical meteorology. Tech. Rep. 240, Air Weather Service (MAC), Scott Air Force Base, Illinois, 62225, United States Air Force, 360 pp.

Barnett, T.P., 1981: Statistical relations between ocean/atmosphere fluctuations in the tropical Pacific. J. Phys. Oceanogr., 11, 1043-1058.

, 1984: Prediction of the El Niño of 1982-1983. Mon. Wea. Rev., 112, 1403-1407.

Cane, M.A., and S.E. Zebiak, 1985: A theory for El Niño and Southern Oscillation. Science, 228, 1085-1086.

Chang, C.-P., and K.-M. Lau, 1980: Northeasterly cold surges and near-equatorial disturbances over the Winter MONEX area during December 1974, Part II. Planetary-scale aspects. Mon. Wea. Rev., 108, 298-312.

, and K.-M. Lau, 1982. Short-term planetaryscale interaction over the tropics and midlatitudes during northern winter. Part I: Contrast between active and inactive periods. Mon. Wea. Rev., 110, 933-946.

, J.E. Erickson, and K.M. Lau, 1979: Northeasterly cold surges and near-equatorial disturbances over the Winter MONEX area during December 1974. Part I. Synoptic aspects. Mon. Wea. Rev., 107, 812-829.

, J.E. Millard, and G.T.J. Chen, 1983: Gravitational character of cold surges during Winter MONEX. Mon. Wea. Rev., 111, 293-307.

Chu, P.-S., and D.N. Sikdar, 1983: Characteristics of sea-level pressure and surface temperature variations during Winter MONEX - December 1978. J. Meteor. Soc. Japan, 61, 717-726.

, and S.-U. Park, 1984: Regional circulation characteristics associated with a cold surge event over East Asia during Winter MONEX. Mon. Wea. Rev., 112, 955-965.

Gill, A.E., 1982: Atmosphere-Ocean Dynamics. Academic Press, 662 pp.

Harrison, D.E., 1984: Where did the strong equatorial westerlies of the 1982 warm event begin? Trop. Ocean-Atmos. Newsl., 24, 17-18.

- and P.S. Schopf, 1984: Kelvin wave-induced anomalous advection and the onset of surface warming in El Niño event. Mon. Wea. Rev., 112, 923-933.

Inoue, M., and J.J. O’Brien, 1984: A forecasting model for the onset of a major El Niño. Mon. Wea. Rev., 112, 2326-2337.

Keen, R., 1982: The role of cross-equatorial cyclone pairs in the Southern Oscillation. Mon. Wea. Rev., 110, 1405-1416.

Lau, K.-M., 1982: Equatorial response to northeasterly cold surges as inferred from satellite cloud imagery. Mon. Wea. Rev., 110, 1306-1313.

Love, G., 1985: Cross-equatorial influence of winter Hemisphere subtropical cold surges. Mon. Wea. Rev., 113, 1487-1498. 
Lukas, R., S.P. Hayes, and K. Wyrtki, 1984: Equatorial sea level response during the $1982-83 \mathrm{El}$ Niño. $J$. Geophys. Res., C6, 10, 425-430.

Luther, D.S., D.E. Harrison, and R.A. Knox, 1983: Zonal winds in the central equatorial Pacific and El Niño. Science, 222, 327-330.

McCreary, J.P., 1976: Eastern tropical ocean response to changing wind systems with application to $\mathrm{El}$ Niño. J. Phys. Oceanogr., 6, 634-645.

Philander, S.G.H., 1981: The response of equatorial oceans to a relaxation of the trade winds. J. Phys. Oceanogr., 11, 176-189.

Ramage, C.S., 1971: Monsoon Meteorology. Academic Press, 296 pp.

- 1975: Preliminary discussion of the meteorology of the 1972-73 El Niño. Bull. Amer. Meteor. Soc., 56, 234-242.

, 1985: E1 Niño variability and tropical cyclones. Trop. Ocean-Atmos. Newsl., 30, 3-5.
Rasmusson, E.M., and T.H. Carpenter, 1982: Variations in tropical sea surface temperature and surface wind fields associated with the Southern Oscillation/El Niño. Mon. Wea. Rev., 110, 354-384.

Sadler, J., M. Lander, J. Maliekal, A. Hori, and L. Oda, 1987: Tropical marine climatic atlas. UHNET report 87-02, Dept. Meteor., University of Hawaii.

van Loon, H., and D.J. Shea, 1985: The Southern Oscillation. Part IV: The precursors south of $15^{\circ} \mathrm{S}$ to the extremes of the oscillation. Mon. Wea. Rev., 113, 2063-2074.

Williams, M., 1979: Inter-hemispheric interaction during Winter MONEX. Proc. Int. Conf. on Early Results of FGGE and large-scale Aspects of its Monsoon Experiments, WMO, 10, 12-16.

Wyrtki, K., 1975: El Niño - the dynamic response of the equatorial Pacific Ocean to atmospheric forcing. J. Phys. Oceanogr., 5, 572-584.

\title{
熱帯外部からの強制と西太平洋における赤道西風の急激な強化 （バースト）：総観的研究
}

\author{
Pao-Shin Chu \\ （ハワイ大学気象学教窣）
}

\begin{abstract}
4 回分の北半球の冬と春（1970-73）での 6 時間每の地上風資料に基づき，赤道西太平洋の仙心部 (〜東経155度) に打ける 2 例の強い西風バーストを特定した。1 例は1972年の4月始めに起こり，他の 例は 5 月始めに起こった。いずれも1972年. ENSO 期間に拈いてペルー沖の海面水温珙常が最大值に達す る前である。

北半球の春に拈いて異常に強い高父圧が北部一中部中国から東岸に移動するとき，フィリッピン諸島 の南東での地上風はすばやく反応し, 東風から北風に転じる。その間, 赤道太平洋の吱西部の地表泊気 王は上昇する。これらのすばやい反纫は拓そらく中緯度での父代と風の不均衡によって引き起こされた 重力波的な運動によるものと思われる。太平洋最西部での局地的な父生の上昇は赤道トラフ地带での父 压の東西傾度を強化し，赤道西太斗洋の中心部での強い西風加速をもたらす。この強化に先立って赤道

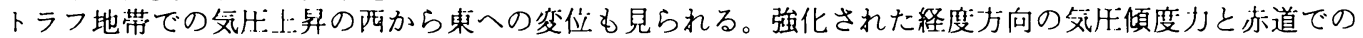
気王上昇の変位が西風バーストを開始させる…つの重要な要素である。固定された観测点の資料から検

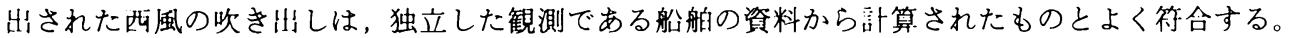

